\title{
NEW PROBLEMS IN INDEMNIFYING AND INSURING DIRECTORS: PROTECTION AGAINST LIABILITY UNDER THE FEDERAL SECURITIES LAWS
}

\author{
JOSEPH W. BISHOP, JR.*
}

In recent years corporate directors and officers, and their lawyers, have become aware that the Damocles' sword of personal liability is as much a part of the furniture of the executive suite as the Bigelow on the floor. Some of the awareness has been stimulated by the imaginative advertising of insurance brokers pushing directors' and officers' liability insurance; some has come from painful personal experience; but the main source has been the proliferation of lawsuits seeking (frequently with success) to impose such liability. Much of this litigation has been based on such traditional grounds as breach of duty to the corporation, but fertile legal imaginations have conceived novel and alarming theories of liability.

Despite the procedural obstacles which courts and legislatures have interposed, the stockholder's derivative suit is anything but a vanishing species of litigation, especially in the federal courts. Federal courts have, for example, been disinclined to require the plaintiff to seek the approval of other stockholders before suing and have hesitated to treat ratification of the management's conduct by a majority of stockholders as a bar to suit.' They have refused to apply state security-for-expenses statutes when the plaintiff manages to state a federal cause of action. ${ }^{2}$ Not even the requirement of Rule 23.1 of the Federal Rules of Civil Procedure that the plaintiff must have owned his stock at the time of the transaction complained of has been applied to suits brought under section 16(b) of the Securities Exchange Act of 1934 (1934 Act) ${ }^{3}$ to recover shortswing profits. ${ }^{4}$ The general attitude of the federal courts to stockholders' suits is perhaps epito-

* Richard Ely Professor of Law, Yale University. B.A. 1936, Dartmouth College; LL.B. 1940, Harvard University.

1. See, e.g., Levitt v. Johnson, 334 F.2d 815 (1st Cir. 1964), cert. denied, 379 U.S. 961 (1965); Rogers v. American Can Co., 305 F.2d 297 (3d Cir. 1962); Weiss v. Sunasco, Inc., 316 F. Supp. 1197 (E.D. Pa. 1970).

2. J.I. Case Co. v. Borak, 377 U.S. 426 (1964).

3. 15 U.S.C. $\S 78 \mathrm{p}(\mathrm{b})(1970)$.

4. Dottenheim v. Murchison, 227 F.2d 737, 739-40 (5th Cir. 1955), cert. denied, 351 U.S. 919 (1956); Blau v. Albert, 157 F. Supp. 816, 818 (S.D.N.Y. 1957). 
mized by the statement of Mr. Justice Black that "derivative suits have played a rather important role in protecting shareholders of corporations from the designing schemes and wiles of insiders who are willing to betray their company's interests in order to enrich themselves."'s

There are other developments which may make the ordinary derivative suit a graver threat to corporate directors and officers than it used to be. Until recently, cases in which directors were held liable for negligence, untainted by self-dealing, were very infrequent, and it seemed that a substantial risk of liability existed only when management was guilty of the sort of conduct described by Justice Black. ${ }^{\circ}$ But there are modern cases which demonstrate that directors may still be held liable for the sort of extreme negligence which amounts to abdication of duty-for example, when a director who knows that dishonest management is looting the company does nothing more than resign quietly. ${ }^{7}$ The Supreme Court's decision two years ago that the stockholder-plaintiff may demand a jury trial in circumstances in which the corporation itself could have done $\mathrm{so}^{8}$ may yet increase the risk of liability for simple negligence, although so far there have been no signs of such a development.

The fastest growing area of personal liability, or at least the one which has caused the most perturbation, is that which arises from the increasingly broad construction given the federal securities laws by the courts. Under the Securities Act of 1933 (1933 fact), ${ }^{9}$ a director may be personally liable to investors who lose money if he signs a registration statement without taking reasonable care to verify its accuracy and completeness, and the statement is later found to contain material misrepresentations or omissions. ${ }^{10}$ Under section $16(\mathrm{~b})$ of the 1934 Act, ${ }^{11}$ he can, of course, be made to pay his profit to the corporation if he sells and buys (or buys and sells) its securities within a six month period-and the courts have given "buy" and "sell" an increasingly liberal construction, at the same time growing more and more generous in computing the amount of his profit. Furthermore,

\footnotetext{
5. Surowitz v. Hilton Hotels Corp., 383 U.S. 363, 371 (1966).

6. See Bishop, Sitting Ducks and Decoy Ducks: New Trends in the Indemmification of Corporate Directors and Officers, 77 Y ALE L.J. 1078, 1095-1101 (1968).

7. DePinto v. Landoe, 411 F.2d 297, 300 (9th Cir. 1969).

8. Ross v. Bernhard, 396 U.S. 531 (1970).

9. 15 U.S.C. $\$ 77 \mathrm{a}$ et seq. (1970).

10. Escott v. BarChris Constr. Corp., 283 F. Supp. 643 (S.D.N.Y. 1968).

11. 15 U.S.C. $\$ 78 \mathrm{p}$ (b) (1970).
} 
as demonstrated by the decision in SEC v. Texas Gulf Sulphur Co., ${ }^{12}$ an insider who trades in his own corporation's securities without disclosing material inside information may, under section $10(\mathrm{~b})$ of the $1934 \mathrm{Act}^{13}$ and rule $10 \mathrm{~b}-5^{14}$ promulgated thereunder, be subject to liability, the extent of which has not yet been clearly determined. Conceivably, the insider might be liable to every public investor who bought or sold during the period when the insider was trading in violation of the rule, for the full amount of each investor's loss. Such precedents as now exist suggest that in the ordinary case, the insider will be compelled at least to disgorge his own profit, plus an amount equal to any profits made by his immediate tippees. ${ }^{15} \mathrm{~A}$ plaintiff who seeks to bring his cause of action within section 10(b) must show some sort of fraud, misrepresentation or nondisclosure "in connection with the purchase or sale of [a] security," but the federal courts have lately evinced a disposition to give very broad and generous constructions to all of these terms. ${ }^{16}$

To make matters worse for peccant insiders, the New York Court of Appeals recently held that insiders who enrich themselves by unloading their company's stock on the basis of a bad, but as yet unpublished, earnings report can be compelled, under state law, to pay their profits to the corporation, on the theory that the inside information was a corporate asset which they had misappropriated for their own benefit. ${ }^{17}$ Such insiders might, moreover, still be liable to the defrauded purchasers under section $10(\mathrm{~b})$.

Thus, corporate directors and officers may be faced with an alarming array of potential litigation and liability when, individually or on behalf of their corporations, they trade in the securities of their own corporation, when they cause it to enter into transactions in

12. 401 F.2d 833 (2d Cir. 1968), cert. denied, 394 U.S. 976 (1969).

13. 15 U.S.C. $\S 78 \mathrm{j}(\mathrm{b})(1970)$.

14. 17 C.F.R. \& $240.10 \mathrm{~b}-5$ (1972).

15. SEC v. Texas Gulf Sulphur Co., 446 F.2d 1301, 1307-08 (2d Cir. 1971), cert. denied, 404 U.S. 1005 (1971); cf. SEC v. Shapiro, 349 F. Supp. 46, 55-56 (S.D.N.Y. 1972); SEC v. Golconda Mining Co., 327 F. Supp. 257 (S.D.N.Y. 1971).

16. See, e.g., Superintendent of Ins. v. Bankers Life and Cas. Co., 404 U.S. 6 (1971); Bailes v. Colonial Press, Inc., 444 F.2d 1241 (5th Cir. 1971); Bryan v. Block \& Blevins Co., 343 F. Supp. 1062 (N.D. Ga. 1972); Collins v. Rukin, 342 F. Supp. 1282 (D. Mass. 1972); Nanfito v. Tekseed Hybrid Co., 34 I F. Supp. 234 (D. Neb. 1972). But cf. Mount Clemens Indus., Inc. v. Bell, 464 F.2d 339 (9th Cir. 1972).

17. Diamond v. Oreamuno, 24 N.Y.2d 494, 248 N.E. $2 d 910,301$ N.Y.S.2d 78 (1969). It is safe to predict that efforts will be made to introduce the rule in other states. $C f$. Gildenhorn v. Lum's, Inc., 335 F. Supp. 329 (S.D.N.Y. 1971). 
which they have some sort of personal interest, or, perhaps, when they are guilty of fairly gross negligence. How can they protect themselves? One way, of course, is to consult counsel and behave so uprightly that not even the most sanguine member of the plaintiffs' bar will think it worthwhile to sue them. But this is a counsel of perfection. So long as stock options and takeover bids are prominent features of the corporate scene, it will not be easy for insiders to refrain from trading personally or on behalf of their companies in their corporations' own securities or those of other corporations. Moreover, it is often impractical to disclose every material development as soon as it occurs. There may be compelling and legitimate business reasons for keeping quiet-for example, in the Texas Gulf Sulphur case, withholding disclosure of information about a possibly rich mineral discovery, at least until the corporation had completed its acquisition of mineral rights in adjoining areas, was crucial. ${ }^{18}$ The law is still in flux; it is not easy for the most experienced lawyers to say with assurance what is adequate disclosure and when it is required, or what is due care in the preparation of a registration statement. Even an honest and prudent executive, guided by counsel with a mine detector, may step on a booby-trap. Similarly, it is sometimes difficult to avoid self-dealing, as when inside directors fix their own compensation as officers, or a director is also interested in a supplier or customer of the company.

The obvious techniques of protection-that is, shifting the cost of litigation and liability - are indemnification by the corporation and insurance. Of course, if an executive goes to jail, neither the corporation nor an insurance company can get him out. But that risk is small in the absence of deliberate violation of the corporation and securities statutes. The more serious risk, which in many cases can be guarded against, is that the director or officer will incur heavy costs in defending against claims of wrongdoing and perhaps in settling them or satisfying judgments.

\section{INDEMNIFICATION BY THE CORPORATION}

Almost all states now have statutes authorizing the corporation

18. See 401 F.2d at 848 . Significantly, the Second Circuit found this argument insufficient to justify non-disclosure by insiders who were trading in the corporation's securitics. But it is arguable that a corporation which is not trading in its own securities has no duty to disclose, at least so long as it continues to have a business reason for silence. See Astor v. Texas Gulf Sulphur Co., 306 F. Supp. 1333, 1338-39 (S.D.N.Y. 1969). 
to indemnify its directors, officers, and, in some instances, employees generally, against the costs of litigation and liability. The most modern and the most permissive provision is section 145 of the Delaware Corporation Law. ${ }^{19}$ The Model Business Corporation Act's provi$\operatorname{sion}^{20}$ is virtually identical. It has been adopted in a number of states already ${ }^{21}$ and is likely to be followed in many others. In many or most of the cases discussed below, the Delaware statute would permit indemnification. Section 145's provisions may, however, raise diffcult questions where litigation against directors or officers is based on asserted violations of the federal securities laws.

The old Delaware statute, ${ }^{22}$ which was copied in many states and is still the law in some of them, ${ }^{23}$ did not deal explicitly with the situation in which the insider is made a party to litigation, not because of anything he did in the course of performing his duties to the corporation but merely because of his status as an insider. In the typical suit under section 10(b) or 16(b) of the 1934 Act, the insider defendant has been trading entirely for his own account, without intending to help or hurt the business of the corporation. But always under section $16(\mathrm{~b})$, and usually under section $10(\mathrm{~b})$, his vulnerability to suit rests on the fact that he is an insider. In Tomash v. Midwest Technical Development Corp.,${ }^{24}$ the Minnesota Supreme Court said that that state's indemnification statute ${ }^{25}$ (which was like the former Delaware provision). did not permit the corporation to pay the litigation expenses of a director who was prosecuted under the Investment Company Act of $1940,{ }^{26}$ giving as one reason the fact that he was not acting in his capacity as a director but was trading for his own account. If an indemnification statute is so construed, a director cannot be indemnified for the costs of defending a suit under section $10(\mathrm{~b})$ or $16(\mathrm{~b})$ even if he is successful on the merits. The new Delaware statute takes care of this problem by providing that an insider may be indemnified, whether he is the defendant in a derivative suit or in

19. Del. Code Ann. tit. 8, § 145 (Supp. 1968).

20. ABA MOdEL BUS. CORP. ACt ANN. $\S 5$ (2d ed. 1971).

21. See, e.g., Nev. Rev. Stat. § 78.751 (1968); ORE. Rev. Stat. § 57.255 (1969); Wash. Rev. CODE ANN. § 23A.08.025 (Supp. 1971).

22. Del. Code AnN. tit. 8, § 122(10) (1953) (originally enacted as Act of Apr. 15, 1943, ch. 125, § 1, [1943] Del. Laws 44).

23. See, e.g., Mo. AnN. Stat. § 351.355 (1966); WIS. Stat. AnN. § 180.04 (1957), as amended, (Supp. 1972).

24. 281 Minn. 21, 160 N.W.2d 273 (1968).

25. Aet of March 20,1951, ch. 98, § 2, [1951] Minn. Laws 133. The Act was later amended in 1969 and is presently codified in MINN. STAT. ANN. $\$ 301.09(7), 301.095$ (1969).

26. 15 U.S.C. \& 80a-1 et seq. (1970). 
a suit brought by an outside buyer or seller of stock, so long as he was acting "in a manner . . . not opposed to the best interests of the corporation." ${ }^{27}$ Some types of insider trading might be held to be "opposed to the best interest of the corporation"-obviously where the corporation itself is the victim and perhaps where public knowledge of the insider's conduct would tarnish the reputation of the company's management. However, in the circumstances disclosed by most suits under section $10(\mathrm{~b})$ or $16(\mathrm{~b})$, the insider's conduct would not seem to affect the company one way or the other.

The former Delaware statute prohibited indemnification whenever the director was adjudged liable, without distinguishing between liability to the corporation in a derivative suit for a breach of duty and liability to a third party for something done in the corporation's behalf. ${ }^{28}$ One could imagine situations in which the director, although found liable in a criminal prosecution or in a civil suit brought by a third party, had acted in good faith and with an honest intent to serve the corporation; such situations, for example, can easily arise under the antitrust laws. The new Delaware statute permits the indemnification even of an insider who is adjudged liable, "if he acted in good faith and in a manner he reasonably believed to be in or not opposed to the best interests of the corporation, and, with respect to any criminal action or proceeding, had no reasonable cause to believe his conduct was unlawful." ${ }^{29}$ It should, however, be noted that under the new statute indemnification is mandatory only when the director's defense succeeds "on the merits or otherwise." When two directorofficers of a corporation and the top management official of one of its subsidiaries tried to compel the company to indemnify them for the cost of defending a criminal prosecution, the Delaware Superior Court held that obtaining the dismissal of one count of a criminal indictment, followed by conviction on all other counts, did not amount to such "success" as would entitle them to reimbursement of even that part of their counsel fees which was attributable to the count dismissed. ${ }^{30}$

27. Del. Code AnN. tit. $8, \S \S 145($ a)-(b) (Supp. 1968) (emphasis added).

28. Del. CODE ANN. tit. 8, § 122(10) (1953) (originally enacted as Act of Apr. 15, 1943, ch. $125, \S 1,[1943]$ Del. Laws 44).

29. Del. Code ANn. tit. 8, § 145(a) (Supp. 1968).

30. Merritt-Chapman \& Scott Corp. v. Wolfson, 264 A.2d 358 (Del. Super. Ct. 1970); cf. Herald Co. v. Bonfils, 315 F. Supp. 497 (D. Colo. 1970), where the district court, under a statute of the old Delaware type, ordercd self-dealing directors who were partially vindicatcd to pay $80 \%$ of their own and the corporation's counsel fees. 
Even if the director is actually adjudged liable to his corporation for a breach of duty, the court is given power under the new statute to authorize indemnification of some or all of his expenses, if, in light of the circumstances, it finds him "fairly and reasonably" entitled to indemnity. ${ }^{31}$ Indemnification might be warranted, for example, where the director's liability is based on a new construction of the antitrust laws, rule $10 \mathrm{~b}-5$ or section $16(\mathrm{~b})$, and a court holds that the law is violated by conduct which, prior to the decision, the director and his lawyer might reasonably have believed permissible.

In practice, of course, the kinds of litigation here considered are very likely to be settled prior to adjudication. If this happens, the Delaware statute permits the corporation to pay the expenses of settlement if (1) directors who are not themselves parties to the litigation, (2) stockholders, or (3) independent legal counsel find that the defendant director or officer acted "in good faith and in a manner he reasonably believed to be in or not opposed to the best interests of the corporation." ${ }^{32}$ Directors who are not parties and the independent legal counsel whom the management selects are likely to be rather charitable in assessing the conduct of a defendant seeking indemnification. A court might disagree with them if their action were challenged in a derivative suit, but the statute does not require that stockholders be informed of such indemnifications and neither do most by-laws. The SEC could probably require that such information be included in proxy solicitations, but it has not yet done so, except to the extent that an indemnification payment in excess of $\$ 30,000$ might be treated as a "material transaction" with the company. ${ }^{33}$

\section{Liability INSURANCE FOR DiReCTORS AND OFFICERS}

Overall, the limits which the Delaware statute places on direct indemnification by the corporation, if they are honestly observed, do

31. Del. Code AnN. tit. 8, § 145(b) (Supp. 1968).

32. See id. $\S 145$ (d) (The quoted language is derived from sections 145(a) and (b)-section 145(d) requires that the disinterested directors, the stockholders, or the independent legal counsel determine that the defendant "has met the applicable standard of conduct set forth in subseetions (a) and (b) of this section.")

33. See proxy rule $14 a-3,17$ C.F.R. $\S 240.14 a-3$ (1972), providing for the identification of the parties on whose behalf the solicitation is made and requiring that "[i]nformation about the directors or nominees must be furnished, including . . . transactions with the issuer in which they have a material interest ..." 17 C.F.R. $\& 24.14 a-101$, schedule 14-A, item 7 (f) (1972), providing for a description of such transactions involving a material interest, does not require disclosure where " $[t]$ he amount involved in the transaction . . . does not exceed $\$ 30,000$." Id. at 360 (instruction 2(c)). 
not seem unreasonable. However, the statute's last subsection permits the corporation, on behalf of directors, to purchase insurance against liability, even if the risk against which they are insured would not be indemnifiable under the other provisions of the statute. ${ }^{34}$ The insurance now on the market is so atrociously drafted that it appears, however unintentionally, to insure against some types of liability for conflict of interest and self-dealing. ${ }^{35}$ Perhaps the Delaware legislature intended to permit insiders to insure themselves against the consequences of their looting the corporation. But, regardless of the legislature's intentions, it is very doubtful that the courts of Delaware or any other state would hold that such a provision repealed the deeprooted policy of the common law against permitting a man to insure himself against the consequences of his intentional wrongdoing. The same rationale should apply to insurance against liability for negligence amounting to a total and deliberate abdication of responsibility which, in fact, is about the only kind of negligence for which directors have so far been held liable.

The draftsmanship of the present policies is so obscure that it is difficult to say whether they are intended to cover liability and the expenses of litigation under the federal securities laws, particularly sections $10(\mathrm{~b})$ and $16(\mathrm{~b})$ of the 1934 Act. The problem stems from the fact that in these situations the director or officer has been trading in the corporation's securities for his own account and not in the course of his employment with the corporation. (Liability under the 1933 Act normally arises out of acts or omissions within the scope of the director's duty to the corporation.) The insuring clauses of each part of the Lloyd's policy, for example, cover loss "by reason of any Wrongful Act (as hereinafter defined) in their respective capacities of Directors or Officers." ${ }^{\text {"36 }}$ This language suggests that the coverage is limited to claims based on the insiders' performance of their duty to

34. Del. Code ANn. tit. 8, § 145(g) (Supp. 1968). See ABA Model Bus. Corp. Act ANN. $\S 5(\mathrm{~g})(2 \mathrm{~d}$ ed. 1971). This provision of the Delaware and Model Business Corporation Acts has drawn heavy fire from Representative Wright Patman. In a letter dated January 28, 1971, to the Chairman of the National Governors Conference, he urged that states adopting the Model Business Corporation Act delete this provision, which, he said, "undermines essential safeguards of federal and state law by authorizing a corporation to furnish its directors and officers with insurance against their own wrongful conduct."

35. See Bishop, supra note 6, at 1088-90.

36. Copies of the forms now in use are contained in the Proceedings of the American Bar Association National Institute on Officers' and Directors' Responsibilities and Liabilitics, Oct. 21-22, 1971. See also Slain, Risk Distribution and Treble Damages: Insurance and Contribution, 45 N.Y.U.L. REv. 263, 275 (1970). 
the corporation. The term "Wrongful Act," however, is defined to include "any matter claimed against them solely by reason of their being such directors," 37 which is broad enough to include litigation under the 1934 Act arising out of an insider's trading for his own benefit. Finally, the second part of the policy, which insures the individual directors and officers against liabilities and expenses for which the corporation cannot indemnify them under applicable law, explicitly excludes claims "for an accounting of profits in fact made from the purchase or sale by the Assureds of Securities of the Company within the meaning of section 16(b) of the Securities Exchange Act of $1934^{\prime \prime} ; 38$ presumably this exclusion would be unnecessary if such claims were not otherwise within the intent of the insuring clause. It is probable that Part I of the policy would be construed to cover any type of indemnification which the corporation is legally authorized to make directly to a director or officer.

\section{Indemnification Against Violation of the Federal Securities} Laws: Special Problems

So far as the law of Delaware and the laws of the numerous other states which follow Delaware's example are concerned, insiders can be indemnified or insured, at the corporation's expense, against most of the risks which they face. But indemnification against liability and expense arising out of alleged violations of the federal securities laws presents the additional problem of whether shifting the burden of liability and/or expense from the individual director to the corporation or an insurance company violates the public policy of the statutes.

The SEC has for many years taken the position that it is against public policy to indemnify a director against personal liability under the 1933 Act for damage caused by misrepresentations or omissions in registration statements. ${ }^{39}$ Although the SEC's rule has been in effect for nearly 30 years, there is still no square judicial holding on the question. However, a recent case, Feit v. Leasco Data Processing Equipment Corp. ${ }^{40}$ may provide some guidance. In a class action

37. See note 36 supra.

38. See note 36 supra.

39. See 17 C.F.R. $\$ 230.460$, note (a) (1972), which obligates issuers to include in registration statements a declaration that "the registrant has been advised that in the opinion of the Securities and Exchange Commission such indemnification is against public policy as expressed in the act and is, therefore, unenforceable."

40. 332 F. Supp. 544 (E.D.N.Y. 1971). 
brought by Feit on behalf of himself and other persons who had exchanged common stock of Reliance Insurance Company for a package of Leasco preferred and warrants, the district court held Leasco and three of its directors liable under section 11 of the 1933 $\mathrm{Act}^{41}$ for negligently failing to include material information in the registration statement filed in connection with the exchange offer. There was, however, no finding of deliberate deceit.

Subsequent to the district court's decision, Leasco informed the court that it proposed to pay the entire judgment (plus plaintiff's costs, expenses and counsel fees in an aggregate of $\$ 330,000)^{42}$ and that it did not intend to seek contribution from the three directors. It asked the court to include in its final judgment a finding that such conduct would be consistent with the public policy of the Act. The SEC; treating Leasco's motion as in effect a declaration of intent to indemnify the directors, intervened to oppose it. The Commission contended in essence that "the overriding purpose of Congress was not so much to impose liability for the benefit of investors injured by a defective registration statement but rather to stimulate diligence on the part of those persons who are actually responsible for the preparation of registration statements," from which it follows that "it is clearly contrary to public policy to allow directors to avoid any consequences for their lack of diligence . . . by indemnification from the issuer." 43

Even if it is true that Congress in 1933 was more intent on penalizing negligent directors in order to encourage direetorial diligence than on giving defrauded investors a method, more useful than their common law remedy, of recouping their losses, it may not follow that negligent directors must always bear the full burden of liability. The 1933 Act contains some built-in anomalies which cast doubt on the practical effect of the SEC's policy, even if the courts agree with the Commission's views.

41. 15 U.S.C. $\S 77 \mathrm{k}(1970)$.

42. Nothing was said about the defendants' costs and counsel fees, but it is a safe bet that Leasco was also willing to bear that burden.

43. Brief for SEC as Intervenor, Feit v. Leasco Data Processing Equip. Corp., 332 F. Supp. 544 (E.D.N.Y. 1971). The Commission relied on dicta in Globus v. Law Research Serv., Inc., 418 F.2d 1276, 1288 (2d Cir. 1969), cert. denied, 397 U.S. 913 (1970), which held unenforceable, because inconsistent with the deterrent policy of tbe 1933 Act, an issuer's contract to indemnify an underwriter who had deliberately acquiesced in the omission of material facts from an offering circular. But the court limited its holding to cases where tbe person to be indemnified has "committed a sin graver than ordinary negligence." Id. 
The fact is that the 1933 Act makes the issuing corporation its prime target for civil liability; it is virtually an insurer of the veracity and completeness of the information in its registration statement. The corporation's only defense, which would rarely, if ever, be available where a public issue is concerned, is to show that a plaintiff knew the true facts and was not misled. Directors, on the other hand, are not liable at all if they acted in good faith and with reasonable diligence. Even if they were guilty of deliberate deceit or negligence, the corporation is still jointly liable to investors, who will normally satisfy their judgment from its assets. Unless the corporation is insolvent, the plaintiff will have no reason to adopt the more troublesome course of proceeding against the assets of the individual directors, and there will be no question of indemnification. ${ }^{44}$ Thus, in the ordinary case when the corporation satisfies the judgment, the problem is whether and how it can be compelled to seek contribution (or even indemnity) from its codefendants.

Section 11(f) of the 1933 Act, ${ }^{45}$ which deals with contribution, does little to illuminate the problem. In substance, it provides that anyone liable under section 11 may recover contribution "as in cases of contract" from any person who would have been liable if sued separately, provided that the person originally paying the judgment was not guilty of fraudulent misrepresentation. ${ }^{46}$ It says nothing about whether and to what extent the parties may shift the burden of liability by agreement among themselves. Writing in 1933, Professor (later Mr. Justice) William O. Douglas and Professor George E. Bates said that "it is probable, though not certain, that the parties liable on the registration statement may by contract allocate inter se their liability. . .."47 The uncertainty has not been cleared up in the intervening four decades.

Although it is doubtful that the SEC could have forced Leasco to seek contribution, a stockholder could have done so in a derivative suit. A court confronted with such a suit would have to decide whether either the policy of the 1933 Act or common law principles required the directors to contribute. On the one hand, it may be argued that because the directors were at least negligent, while the

44. If the corporation is insolvent, even an innocent director, who is clearly entitled to be indemnified for the expenses of his successful defense, would be at best an unsecured creditor.

45. 15 U.S.C. $\S 77 \mathrm{k}(\mathrm{f})(1970)$.

46. Section $18(\mathrm{~b})$ of the 1934 Act, 15 U.S.C. $\$ 78 \mathrm{r}(\mathrm{b})(1970)$, contains a similar provision.

47. Douglas \& Bates, The Federal Securities Act of 1933, 43 YALE L.J. 171, 178 (1933). 
corporation was without fault, as between the directors and the corporation, the former should bear the whole burden because it was their breach of the duty to use reasonable care in managing the corporation's affairs which led to the trouble. On the other hand, it was the corporation which benefited from the violation of the 1933 Act; if it has to return the difference between what it received and the real value of the securities, it loses nothing except the costs of litigation. Ultimately, the Leasco court found that public policy was not violated by an agreement among the parties whereby the three directors paid to Leasco the comparatively small sum of $\$ 5,000$ apiece "in satisfaction of any claims that Leasco may have against said defendants for contribution." 48 What the SEC thought of the settlement is not apparent.

Certainly, no public policy is offended if the corporation pays the expenses of a director's successful defense against an action under section 11. It can also be argued that, even if liability under the statute is intended to be punitive, the cost of even an unsuccessful defense, not being part of the contemplated penalty or of the regulatory scheme, can properly be paid by someone other than the guilty director. ${ }^{49}$ Similarly, one who successfully defends against a suit under section 10 (b) (to the extent that liability is sought to be predicated on breach of a duty which would not exist if the defendant were not a director or officer) or under section 16(b) of the 1934 Act, might properly be indemnified, since vulnerability to such litigation is an incident of employment as a director or officer.

Indemnification of insiders who are not vindicated in section 10(b) or 16(b) litigation presents problems similar to those discussed in connection with suits under section 11 of the 1933 Act. The purpose of liability under section $16(\mathrm{~b})$ is clearly penal rather than compensatory, since the corporation (which gets the insider's illegal profit) has not in fact suffered any harm. Accordingly, public policy would seem to prohibit any form of indemnification against such liability (as distinct from litigation expenses). Where a director

48. Order, Civil No. 69-1329 (E.D.N.Y., July 31, 1972).

49. Cf. Commissioner v. Tellier, 383 U.S. 687 (1966), in which it was held that public policy was not violated when a securities dealer was allowed to deduct as a business expensc the cost of an unsuccessful defense against a criminal prosecution under the 1933 Act. The Court considered that the public policy in favor of adequate defense against criminal charges was stronger than any policy expressed in the penal provisions of the 1933 Act. Tellier had not attempted to deduct the fine he paid, and doubtless no such deduction would have been permitted. 
or officer is found liable under section 10(b), the propriety of indemnification may depend on whether the principal purpose of such liability is considered to be compensation of the victims or punishment and deterrence of the misuse of inside information. The fact that section 32 of the $1934 \mathrm{Act}^{50}$ imposes criminal penalties for willful violations of the Act suggests that punishment is not the prime purpose of civil liability under section 10 (b). This distinction may depend on whether, in the particular case, the insider's conduct was a deliberate violation of the statute, or was done in the reasonable but mistaken belief that it was lawful. However, the Fourth Circuit held in Baumel v. Rosen ${ }^{51}$ that victims of even an apparently deliberate violation of section 10(b) by insiders purchasing stock were entitled only to damages and not to the punitive remedy of rescission. The court, in part, based its conclusion on a finding that the purpose of section 10(b) was compensatory rather than punitive. ${ }^{52}$

The SEC's position in the Leasco case was not strengthened by the fact that it has never objected to insurance protecting both the corporation and the directors against liability under the 1933 Act, even if the corporation pays the whole cost of such insurance. If it is against public policy for directors to make contractual arrangements relieving themselves of fear of liability for negligent violations of the 1933 Act, that public policy should forbid insurance, even if the director pays for it himself. But it has never been thought in such other contexts as automobile insurance that the role of civil liability in deterring careless driving makes it illegal for drivers to insure themselves against liability.

Perhaps the validity and enforceability of insurance against liability and expense under the securities laws is an academic question. The legality of such insurance might be questioned in a stockholder's derivative suit, if the stockholder discovered that a policy existed and if the premiums were so great-and they have recently been raised to very high levels - that the saving to the corporation by forbidding it to pay for such insurance would justify the allowance of a substantial fee to the plaintiff stockholder's lawyer. A state agency regulating insurance might question such policies. It would not be likely to do

50. 15 U.S.C. $\& 78 \mathrm{ff}(1970)$.

51. 412 F.2d 571 (4th Cir. 1969).

52. To similar effect, see Globus v. Law Research Serv., 418 F.2d 1276 (2d Cir. 1969), cert. denied, 397 U.S. 913 (1970); Green v. Wolf Corp., 406 F.2d 291 (2d Cir. 1968), cert. denied, 395 U.S. 977 (1969). 
so-the principal result would be to cause corporations and insiders to buy insurance in London. The insurer might itself raise the issue-but this is very unlikely, since the sale of such policies has probably been too lucrative to abandon. In one way or another directors will probably manage to protect themselves against such liability, so long as it is based on nothing worse than negligence. It is unlikely that the SEC will hold that it is illegal for a director to purchase insurance against such liability, and still more unlikely that the courts will do so. But if the director can purchase such insurance, the corporation can pay for it. As the Commission has conceded, the policy's coverage can be made to include directors as well as the securities issuer for little or no additional premium. If insurers were to justify a higher premium by arguing that the addition of negligent directors would prevent the insurance company's being subrogated to the corporation's right of contribution, it would as a practical matter be very difficult to keep the corporation from paying the additional premium simply by increasing the director's compensation in an amount sufficient to pay for insurance. 